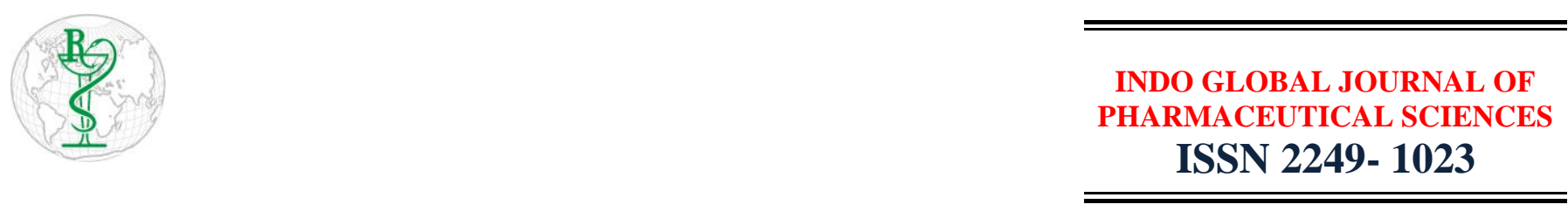

\title{
Role of Natural Products in Treatment of Tuberculosis
}

\author{
Tanvir Kaur ${ }^{* 1}$, Pooja Sharma ${ }^{1,2}$, Dinesh Kumar ${ }^{1}$ \\ ${ }^{1}$ Sri Sai College of Pharmacy, Manawala, Amritsar-143115, Punjab, India. \\ ${ }^{2}$ Department of Pharmaceutical Sciences and Drug Research, Punjabi University Patiala
}

Address for Correspondence: Tanvir Kaur; kaurt13@gmail.com

\begin{tabular}{l} 
Received: \\
01.03.2019 \\
Accepted: \\
25.03.2019 \\
Keywords \\
Tuberculosis, \\
MDR-TB, XDR- \\
TB, Natural \\
drugs. \\
\hline
\end{tabular}

Indo Global Journal of Pharmaceutical Sciences( ISSN 2249 1023; CODEN- IGJPAI; NLM ID: 101610675) indexed and abstracted in CrossRef (DOI Enabling), UGC CARE Journal List, EMBASE(Elsevier), National Library of Medicine (NLM) Catalog, ResearchGate, Publons, CAS (ACS), Index Copernicus, Google Scholar and many more. For further details, visit http://iglobaljournal.com

This is a special issue as an outcome of 'RAPSCON-2019' sponsored by APTI and organized by Sri Sai College of Pharmacy, Manawala, Amritsar, Punjab, India. Relaxation offered in journal format.
Cite this article as: Kaur, T.; Sharma, P.; Kumar, D. Role of Natural Products in Treatment of Tuberculosis. Indo Global J. Pharm. Sci., 2019; 9(2Suppl.): 120. DOI: http://doi.org/10.35652/IGJPS.2019.92S18 .
ABSTRACT: Tuberculosis is a serious infectious bacterial disease. The disease is highly contagious and mostly transmitted from person to person, usually by bacteria and it is mostly transmitted by inhaling bacteria-carrying air droplets. Tuberculosis most generally attacks the lungs, but it can also infect other organs. It has resulted in progressive increase in number of orphans due to parental deaths which is estimated to be 10 million out of which $6 \%-15 \%$ is maternal mortality, which counts up to $15 \%-34 \%$ if only indirect are taken into account. Tuberculosis screening is done using an intelligible clinical technique that necessitates a multidisciplinary research. The use of allopathic drugs in such a convoluted disease gives rise to more dangerous complexities like cross resistance whereas natural drugs have proven to be better in this scenario. The investigation of new remedies for the successful weakening of the unhealthy condition associated with tuberculosis is the crucial requirement. Anti-tuberculosis agents: Actinobacteria, Artemisia аппиа, Camellia sinesis. () 2019 iGlobal Research and Publishing Foundation. All rights reserved. 